\title{
DESAIN PROSES PENGERINGAN SEMPROT UNTUK PRODUKSI TEPUNG KARET ALAM DARI LATEKS
}

\author{
A. Zainal Abidin*1, Afrizal Vachlepi ${ }^{2}$ \\ ${ }^{1}$ Kelompok Keahlian Pengembangan dan Rekayasa Produk Teknik Kimia \\ Program Studi Teknik Kimia, Fakultas Teknologi Industri, Institut Teknologi Bandung \\ Jalan Ganesha 10, Bandung 40132 \\ ${ }^{2}$ Balai Penelitian Sembawa - Pusat Penelitian Karet \\ Jalan Raya Palembang-Pangkalan Balai Km 29, Banyuasin Sumatera Selatan \\ Email: zainal@che.itb.ac.id; Vachlepi_BPS@yahoo.com
}

\begin{abstract}
Abstrak
Kandungan air yang tinggi di dalam lateks dapat mengakibatkan lateks mudah rusak, biaya transportasinya tinggi, kebutuhan kemasannya besar, dan penanganannya yang ketat karena lateks mengandung amonia sebagai bahan pencegah kerusakan. Salah satu cara mengatasinya adalah mengkonversi lateks tersebut menjadi tepung karet alam dengan teknologi pengeringan semprot (spray drying). Di sini akan dipaparkan perancangan proses produksi tepung tersebut, formulasi umpannya, dan pengering semprot (spray dryer) yang digunakan untuk mengeringkan lateks. Kinerja dari pengering semprot dievaluasi dengan teknik simulasi. Rancangan proses produksi dimulai dari pengumpulan lateks, pemeriksaan kualitas lateks, penyaringan, penambahan zat aditif, dan pengeringan semprot. Formulasi umpan terdiri dari lateks segar, antikoagulan 1\%-b, dan antilengket $2 \%$-b. Ruang pengering semprot dirancang berdasarkan laju alir umpan lateks $6 \times 10^{-5} \mathrm{~m}^{3} / \mathrm{s}$ dengan kadar air $80 \%$-b, densitas $920 \mathrm{~kg} / \mathrm{m}^{3}$, suhu umpan $27{ }^{\circ} \mathrm{C}$, dan udara pengering $140{ }^{\circ} \mathrm{C}$. Nozzle bertekanan dipilih untuk alat ini. Hasil desain menunjukkan bahwa pengering semprot memerlukan diameter lubang nozzle $3,5 \mathrm{~mm}$,volume ruang pengering $0,8 \mathrm{~m}^{3}$, tinggi bagian silinder $850 \mathrm{~mm}$, kerucut $870 \mathrm{~mm}$, dan diameter $1000 \mathrm{~mm}$. Waktu pengeringan umpan berlangsung selama 0,134 detik dengan waktu lintasan 1,80 detik. Hasil simulasi menunjukkan pengering semprot mampu menghasilkan tepung karet alam dengan kadar air sekitar 0,32-0,56\%.
\end{abstract}

Kata kunci: lateks, perancangan, pengeringan semprot, simulasi

\begin{abstract}
SPRAY DRYING PROCESS DESIGN FOR THE PRODUCTION OF NATURAL RUBBER POWDER FROM LATEX. High water content in latex may result in perishable condition, high transportation costs, large packing needs, and handling difficulty due to the use of ammonia to prevent its coagulation. A solution to this problem is to convert the latex into rubber powder using spray drying. This work describes the design of the rubber powder production process, feedstock formulation, and the design of the dryer. Spray dryer performance is evaluated by simulation. The production process involves latex collection, quality inspection, filtration, addition of additives, and spray drying. Feedstock formulation consists of fresh latex, $1 \%-\mathrm{w}$ anticoagulant, and $2 \%$-w non-stick agent. The drying chamber is designed with a latex feed rate of $6 \times 10^{-5} \mathrm{~m}^{3} / \mathrm{s}$, moisture content of $80 \%-\mathrm{w}$, density of 920 $\mathrm{kg} / \mathrm{m}^{3}$, feed temperature of $27^{\circ} \mathrm{C}$, and drying air temperature of $140{ }^{\circ} \mathrm{C}$. A pressurized-type nozzle is selected for the dryer. Design calculation results indicate that the dryer requires a nozzle diameter of $3.5 \mathrm{~mm}$, chamber volume of $0.8 \mathrm{~m}^{3}$, cylindrical section height of $850 \mathrm{~mm}$, conical section height of $870 \mathrm{~mm}$, and a chamber diameter of $1000 \mathrm{~mm}$. Drying time is 0.134 sec, with an overall residence time of 1.80 second. The dryer is predicted to produce natural rubber powder with a moisture content of 0.32-0.56\%-w.
\end{abstract}

Keywords: latex, design, spray drying, simulation

* penulis korespondensi 


\section{PENDAHULUAN}

Karet alam memiliki beberapa keuntungan yang tidak terdapat pada polimer lain seperti elastisitas yang baik, kepegasan pantul yang baik, ketahanan kikis dan sobek baik, ketahanan lentur baik, dan fleksibitas yang baik. Pembuatan barang jadi karet alam secara umum dibagi menjadi dua proses yang berdasarkan jenis bahan baku karet yang digunakan, yaitu lateks pekat dan karet padat. Karet sit dan karet remah merupakan contoh karet padat.

Lateks pekat masih berupa cairan yang mengandung air sekitar 35-40\%. Dengan jumlah produksi lateks pekat Indonesia sebesar 12,93 ribu ton pada tahun 2010 yang berarti terdapat sekitar 4,52-5,17 ribu ton air yang harus diangkut ke pabrik barang jadi. Jumlah ini berpengaruh pada proses penanganan dan pengangkutannya. Beberapa pengaruh kadar air lateks pekat selama proses transportasi antara lain meningkatkan biaya transportasi karena sebagian biaya digunakan untuk mengangkut air, penggunaan kemasan yang besar, dan memerlukan penanganan yang lebih ketat karena adanya ammonia sebagai antikoagulan. Tanpa antikoagulan lateks dapat menggumpal secara alami (Balai Penelitian Sembawa, 2003), yang berarti lateks pekat sudah tidak dapat digunakan untuk memproduksi barang jadi lagi. Dalam lateks terdapat bahan-bahan nonrubber yang mudah rusak oleh mikroba sehingga berpengaruh terhadap penanganan dan sifat fisik karet (Solichin, 2000).

Peningkatan efisiensi transportasi dapat dilakukan dengan menghilangkan kandungan air dalam lateks segar. Salah satu cara yang dapat digunakan adalah membuatnya menjadi tepung karet. Zbicinski dan Zietara (2004) menyatakan bahwa penurunan kandungan dan aktivitas air mempunyai pengaruh yang positif terhadap kualitas produk. Tepung yang kering cenderung lebih mudah dikemas dengan kualitas terjaga. Tidak hanya itu, dengan kondisi yang kering umur simpan lateks lebih tahan lama. Lateks cair sangat sensitif terhadap pertumbuhan mikrob karena di dalam lateks terkandung protein. Teknologi yang dapat digunakan untuk membuat tepung karet adalah pengeringan semprot (spray drying). Salah satu keuntungannya adalah dapat digunakan untuk mengeringkan produk yang sensitif terhadap panas, seperti produk makanan dan bahan farmasi (Huang dan Mujumdar, 2007).

Tujuan penelitian ini adalah merancang proses produksi tepung karet alam dari lateks, merancang formulasi umpan untuk produksi tepung karet alam yang tidak lengket, merancang pengering semprot dan mempelajari kinerja pengering semprot menggunakan simulasi Computational Fluid Dynamic (CFD). Data karakteristik umpan diperoleh dari lateks segar yang berasal dari kebun percobaan Balai Penelitian SembawaPusat Penelitian Karet dan berdasarkan studi literatur. Pengering semprot yang dipilih adalah model aliran searah dan sistem siklus terbuka.

\section{METODE}

Penelitian ini dibagi menjadi beberapa tahapan, yaitu pengumpulan data karakteristik lateks, perancangan proses produksi tepung karet alam, perancangan formulasi lateks umpan, perancangan pengering semprot, simulasi kinerja pengering semprot, dan analisis hasil. Data karakteristik lateks dikumpulkan dari studi literatur dan analisis di laboratorium berupa kadar karet kering, kadar air, dan viskositas.

Proses produksi tepung karet alam dirancang berdasarkan skema pengeringan karet konvensional seperti karet sit. Rancangan proses ini disusun sejak lateks segar dikumpulkan dari kebun karet sampai pengolahan sehingga menjadi produk akhir berupa tepung karet alam. Formulasi umpan lateks yang diproses menjadi tepung karet alam dirancang berdasarkan studi literatur.

Rancangan pengering semprot untuk memproduksi tepung karet alam dilakukan dalam beberapa tahap, yaitu penentuan basis perhitungan, penentuan jenis dan diameter mulut penyemprot (nozzle), perhitungan waktu pengeringan, penentuan ruang pengering semprot serta uji kinerjanya. Tabel 1 memuat basis perhitungan perancangan pengering semprot.

Jenis mulut penyemprot yang digunakan pada pengering semprot untuk lateks adalah mulut penyemprot bertekanan (pressurized nozzle) karena memiliki keuntungan seperti bentuknya simpel, tidak ada bagian yang bergerak, dan konsumsi energi rendah. Umpan lateks masuk ke bagian tengah mulut penyemprot secara tangensial dan keluar dari lubang mulut penyemprot berbentuk kerucut dengan sudut bervariasi 
sekitar $40-140{ }^{\circ} \mathrm{C}$. Filkova dan Mujumdar (1995) menyatakan bahwa diameter lubang untuk mulut penyemprot bertekanan biasanya $0,4-4,0 \mathrm{~mm}$.

Tabel 1. Basis Perhitungan Alat Pengering Semprot

\begin{tabular}{lcc}
\hline \multicolumn{1}{c}{ Parameter } & Nilai & Satuan \\
\hline Laju alir umpan & 0,00006 & $\mathrm{~m}^{3} / \mathrm{s}$ \\
Densitas umpan & 920 & $\mathrm{~kg} / \mathrm{m}^{3}$ \\
Kadar air umpan & 80 & $\%$ \\
Total padatan umpan & 20 & $\%$ \\
Suhu umpan & 27 & ${ }^{\circ} \mathrm{C}$ \\
Suhu udara pengering & 140 & ${ }^{\circ} \mathrm{C}$ \\
Suhu udara sekitar & 27 & ${ }^{\circ} \mathrm{C}$ \\
Kelembapan udara & 85 & $\%$ \\
Sudut semprot mulut & 60 & \\
penyemprot & & \\
\hline
\end{tabular}

Kecepatan tangensial umpan di dalam ruang pengering untuk mulut penyemprot bertekanan dapat dihitung dengan menggunakan persamaan di bawah ini (Schweitzer, 1979):

$U_{T}=\frac{Q}{\pi * r_{o}^{2}}$

Kecepatan aksial akan dihitung dengan menerapkan neraca massa yang melewati lubang dan memperhitungkan udara yang ada di dalam lubang mulut penyemprot (Kievert, 1997):

$U_{A}=\frac{Q}{\pi\left(r_{o}^{2}-r_{a}^{2}\right) \cos (1 / 2 \alpha \dot{\alpha})}$

Diameter tetesan dapat diprediksi menggunakan korelasi empirik yang biasa dipergunakan dalam mulut penyemprot bertekanan (Schweitzer, 1979):

$D p=286\left(d_{o}+0,17\right) \exp \left[\frac{13}{U_{A}}-0,0094 U_{T}\right](3)$

Waktu pengeringan aktual dapat diperkirakan secara kasar dari ekspresi teoritikal dengan diameter tetap $D_{p}$ (Schweitzer, 1979) :

$\theta_{d}=\frac{\lambda \cdot W \cdot \rho_{s} \cdot D_{p}^{2}}{12 \cdot k_{f}\left(T_{a}-T_{s}\right)}$

Ruang pengering mempunyai geometri berbentuk silinder-kerucut dengan sudut kerucut bagian bawah $60{ }^{\circ} \mathrm{C}$ (Gambar 1). Penentuan dimensi ruang pengering hanya dilakukan untuk silinder bagian atas yang mencakup tinggi minimum $h^{\prime}$ dan diameter Dch. Tinggi minimum dihitung dari kecepatan tangensial dan waktu pengeringan sebagai berikut:

$h^{\prime}=U_{T} x \theta_{d}$

Sedangkan diameter minimum $\left(\mathrm{D}_{\mathrm{ch}}\right)$ ruang pengering semprot dihitung dari kecepatan aksial dan waktu pengeringan, seperti di bawah ini:

$D_{c h}=U_{A} \times \theta_{d} \times 2$

Tahap berikutnya menghitung tinggi kerucut bagian bawah $\left(\mathrm{h}_{\text {cone }}\right)$ dari ruang pengering menggunakan persamaan matematik di bawah ini:

$h_{\text {cone }}=\sqrt{\left(D_{c h}\right)^{2}-\left(1 / 2 D_{c h}\right)^{2}}$

Volume ruang pengering dihitung dengan persamaan ini:

$V=\left(\pi r_{c}^{2} h^{\prime}\right)+\left(0,33 \pi r_{c}^{3}\right)$

Perpindahan tetesan di dalam ruang pengering dianalisis dalam istilah waktu lintasan (trajectory time). Waktu lintasan dari umpan lateks dapat ditentukan menggunakan korelasi empirik yang diberikan di bawah ini (Schweitzer, 1979):

$\theta_{t}=\left(\frac{64}{\pi}\right)^{2 / 3} \frac{V^{2 / 3}}{6,4 U_{A} d_{o}^{\prime}}$

$d_{o}^{\prime}=d_{o}\left(\rho_{s} / \rho_{a}\right)^{1 / 2}$

Simulasi kinerja pengering semprot dilakukan untuk melihat profil perubahan kadar air umpan dan diameter tetesan. Variasi simulasi dilakukan untuk suhu udara pengering $\left(140,150,160,170\right.$, dan $\left.180^{\circ} \mathrm{C}\right)$ dan kadar air umpan $(65,70,75$, dan $80 \%)$. Simulasi kinerja pengering semprot dilakukan dengan menggunakan pendekatan CFD.

Model yang digunakan dalam simulasi CFD adalah model tetesan diskret, model k- $\varepsilon$, dan model perpindahan spesies. Model tetesan diskret digunakan untuk menggambarkan proses penyemprotan umpan ke dalam ruang pengering dan tipe mulut penyemprot yang dipilih adalah pressure swirl atomizer. Model k- $\varepsilon$ digunakan untuk menggambarkan aliran turbulen yang terjadi di ruang pengering. Model ini merupakan model aliran turbulen lengkap yang paling sederhana. Model $k-\varepsilon$ biasa digunakan dalam praktek keteknikan karena memerlukan sedikit data dalam komputasi. Konstanta besaran nilai energy kinetik turbulen $(\mathrm{k})$ adalah $0,027 \mathrm{~m}^{2} / \mathrm{s}^{2}$ dan laju disipasi turbulen $(\varepsilon)$ sebesar $0,37 \mathrm{~m}^{2} / \mathrm{s}^{3}$ (Saleh, 2010). 


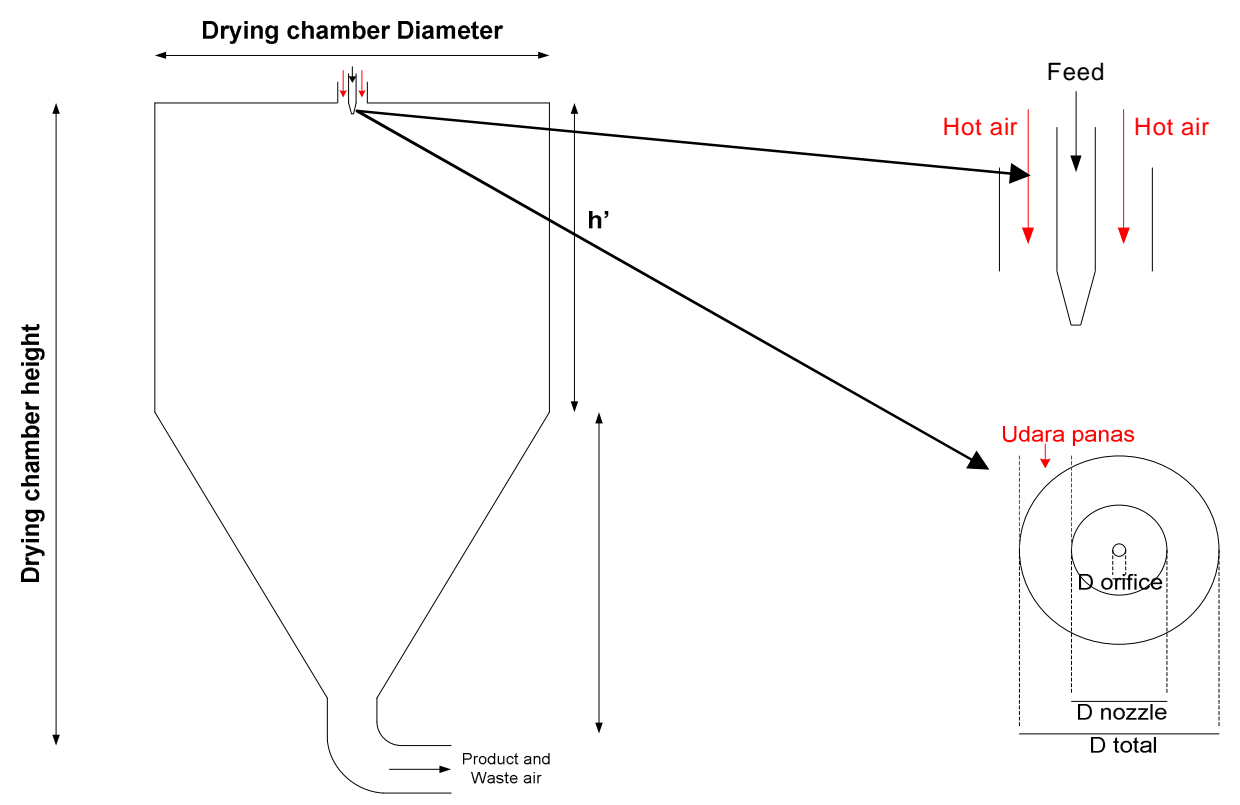

Gambar 1. Geometri ruang pengering dan posisi mulut penyemprot dari pengering semprot

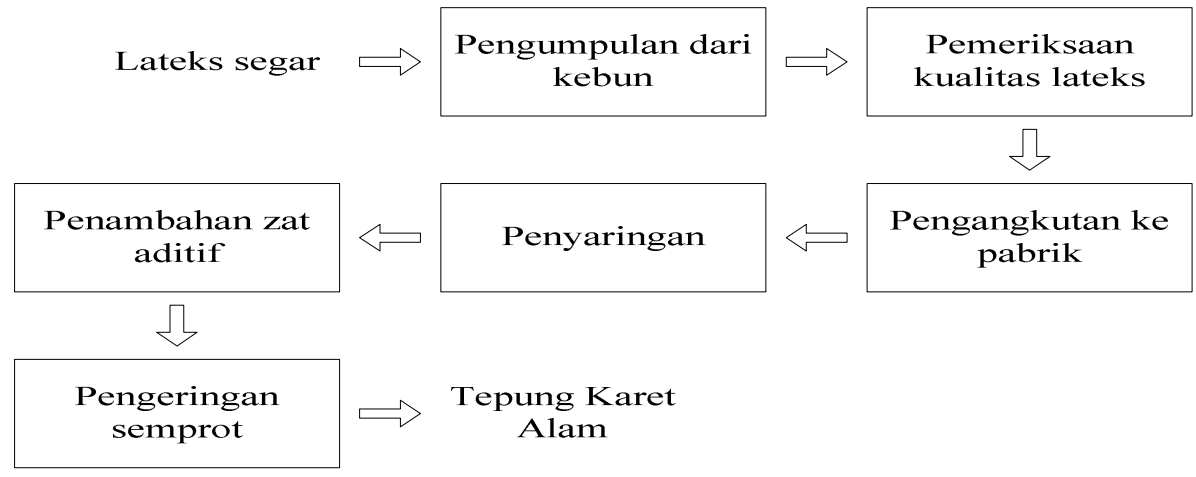

\section{Gambar 2. Proses produksi tepung karet alam}

Spesies transport model diperlukan untuk proses pengeringan yang melibatkan perpindahan massa dan energi dari tetesan umpan ke udara pengering. Dalam model ini ditentukan spesies dari fluida yang terdapat dan akan terbentuk di dalam ruang pengering. Jenis spesies yang dipilih berupa campuran terdiri atas oksigen, nitrogen, dan uap air. Uap air yang terbentuk dan terakumulasi ini sebagian besar berasal dari penguapan air dari tetesan umpan.

\section{HASIL DAN PEMBAHASAN}

\section{Perancangan Proses Produksi dan} Formulasi Tepung Karet Alam

Rancangan proses produksi tepung karet alam diawali dengan pengumpulan lateks segar dari kebun sampai diolah menjadi produk tepung karet alam di pabrik pengolahan mengikuti tahapan seperti pada Gambar 2. Lateks segar yang ditampung di mangkuk sadap di setiap pohon karet dikumpulkan untuk diangkut ke tempat pengumpulan hasil yang terletak di kebun karet.

Untuk mengetahui kualitas dari lateks segar yang sudah dikumpulkan, terlebih dahulu dilakukan pemeriksaan yang terdiri dari kadar karet kering, kadar air, dan koagulasi. Lateks yang sudah mengalami prakoagulasi ataupun koagulasi harus dipisahkan dari lateks karena sudah tidak dapat dijadikan bahan baku untuk pembuatan barang jadi dari lateks. Setelah itu, lateks diangkut ke pabrik pengolahan untuk diolah menjadi tepung karet alam.

Sebelum ditampung dalam bak penampungan di pabrik pengolahan, lateks 
segar dari kebun harus disaring terlebih dahulu. Penyaringan ini dilakukan untuk menghilangkan kotoran di dalam lateks (seperti ranting dan daun) dengan menggunakan saringan 40-60 mesh (Balai Penelitian Sembawa, 2003). Tahap selanjutnya adalah penambahan zat aditif berupa antikoagulan dan antilengket. Lateks yang sudah dicampur dengan zat aditif dikeringkan menggunakan pengering semprot. Menurut Patel dkk. (2009) proses pengeringan semprot secara umum dibagi menjadi lima tahapan, yaitu penyiapan umpan, penyemprotan larutan umpan ke dalam ruang pengering, kontak umpan dengan media pengering di dalam ruang pengering, proses pengeringan dan pemisahan.

Larutan amonia 20\% dan natrium sulfit $\left(\mathrm{Na}_{2} \mathrm{SO}_{3}\right)$ merupakan zat antikoagulan yang biasa digunakan dalam pengolahan karet alam. Untuk teknologi pengeringan semprot, sifat lengket ini dapat dicegah dengan dua cara, yaitu sebelum proses penyemprotan dan pada saat proses penyemprotan. Cara pertama, menambahkan lateks dengan bahan antilengket sebelum disemprotkan. Contoh dari beberapa bahan antilengket ini, yaitu oksida magnesium, serbuk talk, trikalsium fosfat, belerang, carbon black, kapur tulis, dan kapur semen. Cara kedua adalah dengan menambahkan bahan padat pada saat proses penyemprotan sehingga pada saat kering partikel karet alam terselimuti dengan bahan tersebut. Bahan yang dapat digunakan, yaitu tanah yang banyak mengandung senyawa $\mathrm{SiO}_{2}$. Dengan mempertimbangkan kedua

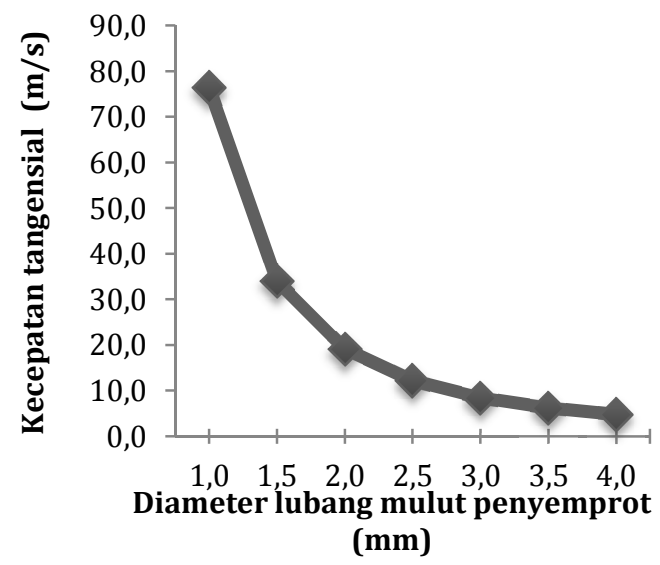

(a) kebutuhan aditif tersebut, maka formulasi umpan yang tepat untuk produksi tepung karet terdiri atas lateks segar, antikoagulan 1 $\%$-b, dan antilengket $2 \%$-b.

\section{Perancangan Pengering Semprot}

Gambar 3 menunjukkan pengaruh diameter lubang mulut penyemprot terhadap kecepatan tangensial dan kecepatan aksial dari tetesan umpan. Kecepatan tangensial dihitung menggunakan persamaan (1) dan kecepatan aksial dihitung dari persamaan (2) dengan sudut penyemprotan $60{ }^{\circ} \mathrm{C}$. Semakin besar diameter lubang mulut penyemprot, maka semakin lambat kecepatan tetesan umpan ke arah tangensial dan semakin cepat kecepatan ke arah aksial.

Perbedaan kecepatan tangensial yang diakibatkan oleh perbedaan diameter lubang mulut penyemprot cukup besar (Gambar 3.a). Kecepatan tangensial terbesar dihasilkan oleh mulut penyemprot berdiameter $1 \mathrm{~mm}$, yaitu sebesar 76,43 m/s dan kecepatan terkecil pada diameter $4 \mathrm{~mm}$ sebesar $4,78 \mathrm{~m} / \mathrm{s}$. Sedangkan untuk kecepatan ke arah aksial, tidak terlalu dipengaruhi oleh diameter lubang mulut penyemprot (Gambar 3.b). Perbedaan kecepatan yang dihasilkan antara mulut penyemprot berdiameter lubang $1 \mathrm{~mm}$ $(2,51 \mathrm{~m} / \mathrm{s})$ dan berdiameter $4 \mathrm{~mm}(4,39 \mathrm{~m} / \mathrm{s})$ hanya sebesar $1,88 \mathrm{~m} / \mathrm{s}$. Hal ini terjadi karena adanya pengaruh udara dan sudut penyemprotan. Diameter lubang 2,5 $\mathrm{mm}$ merupakan titik di mana perubahan kecepatan besar terjadi, baik ke arah tangensial maupun ke arah aksial.

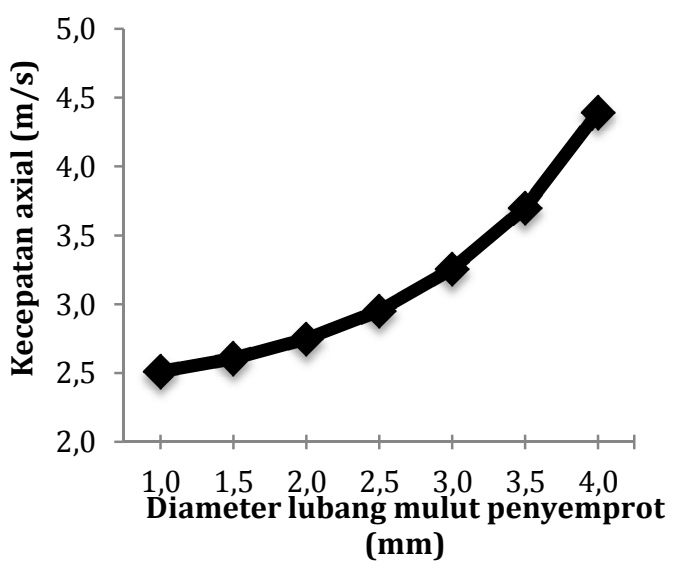

(b)

Gambar 3. Profil kecepatan (a) tangensial dan (b) kecepatan aksial umpan lateks 
Ukuran diameter lubang mulut penyemprot juga berpengaruh terhadap perhitungan prediksi diameter tetesan umpan (persamaan 3). Semakin besar diameter lubang mulut penyemprot, maka semakin besar prediksi diameter tetesan yang dibentuk (Gambar 4). Berdasarkan Gambar 3 dan 4, dalam rancangan ini diameter lubang mulut penyemprot yang dipilih untuk pengering semprot tepung karet alam adalah 3,5 mm. Mulut penyemprot berdiameter ini diprediksi akan menghasilkan kecepatan tangensial sebesar $6,24 \mathrm{~m} / \mathrm{s}$, kecepatan aksial $3,7 \mathrm{~m} / \mathrm{s}$ dan diameter tetesan $25 \mu \mathrm{m}$.

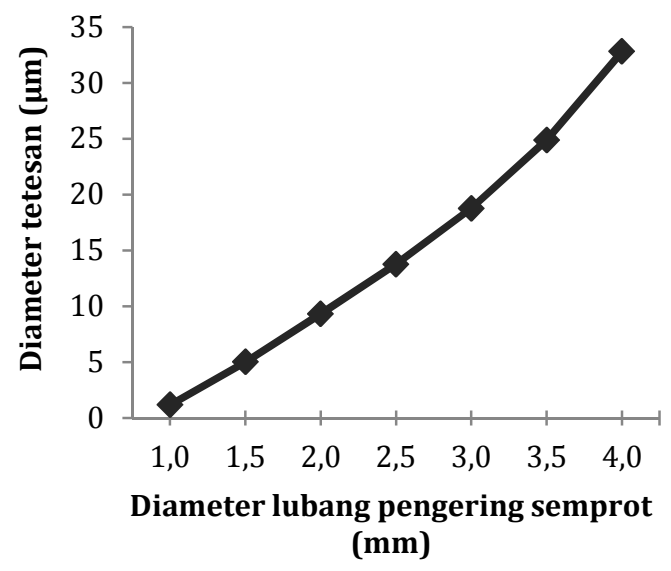

Gambar 4. Prediksi diameter tetesan umpan pada berbagai diameter lubang mulut penyemprot

Ukuran diameter mulut penyemprot 3,5 mm dipilih karena menghasilkan ruang pengering dengan diameter dan tinggi bagian silinder berukuran hampir sama (proporsional). Hal ini dapat dilihat dari kecepatan ke arah aksial, yang menentukan jari-jari dari ruang pengering hampir dua kali dibandingkan kecepatan tangensial yang digunakan untuk menentukan tinggi ruang pengering. Pada ukuran ini, dimensi ruang pengering yang dirancang relatif tidak terlalu besar. Sisi positif lainnya, mulut penyemprot dengan ukuran lubang sebesar ini cukup banyak tersedia di pasaran.

Dari perhitungan menggunakan persamaan (4) diketahui bahwa waktu pengeringan umpan berkadar air $80 \%$ dengan laju alir $6 \times 10^{-5} \mathrm{~m}^{3} / \mathrm{s}$ pada suhu $140{ }^{\circ} \mathrm{C}$ adalah 0,134 detik. Waktu pengeringan ini digunakan untuk menentukan dimensi ruang pengering semprot. Ukuran ruang pengering harus lebih besar daripada panjang lintasan yang diperlukan umpan saat proses pengeringan terjadi. Tujuannya agar tetesan umpan kering sebelum partikel menyentuh dinding ruang pengering.

Perhitungan menggunakan persamaan (5) didapati bahwa tinggi minimum silinder dari ruang pengering adalah 836,76 $\mathrm{mm}$. Sedangkan untuk diameter minimum yang didapat sebesar 992,17 mm (persamaan 6). Untuk memastikan proses pengeringan berjalan sempurna, maka tinggi dan diameter ruang pengering ditingkatkan menjadi 850 $\mathrm{mm}$ dan $1000 \mathrm{~mm}$. Hal yang penting dalam menentukan ukuran diameter ruang pengering adalah dengan menjaga agar tetesan atau partikel basah tidak menumbuk dinding ruang pengering sebelum proses pengeringan selesai, sehingga ukuran ruang pengering dibuat lebih besar. Diameter ruang pengering sebesar 2,5-9 m lazim ditemui.

Perhitungan menggunakan persamaan (7) mendapatkan tingggi dari bagian kerucut ruang pengering sebesar $870 \mathrm{~mm}$. Dengan demikian volume ruang pengering dari persamaan 8 adalah $0,8 \mathrm{~m}^{3}$. Perhitungan menggunakan persamaan (9) menghasilkan waktu lintasan umpan di dalam ruang pengering berbentuk silinder sekitar 1,80 detik. Hal ini berarti proses pengeringan berjalan dengan baik karena waktu lintasan jauh lebih lama dibandingkan waktu pengeringan $(0,134$ detik).

\section{Simulasi Kinerja Pengering Semprot}

Proses pengeringan yang terjadi pada umpan lateks karet alam dapat dilihat dari perubahan kadar airnya. Profil perubahan kadar air umpan lateks karet alam pada berbagai suhu udara pengering yang diperoleh disajikan pada Gambar 5. Kadar air umpan lateks mengalami penurunan selama proses pengeringan. Hal ini menunjukkan bahwa telah terjadi proses pengeringan atau penguapan pelarut (air) yang ada di dalam umpan. Kadar air pada produk lateks kering dipengaruhi oleh kadar air awal. Umpan dengan kadar air 80\% diprediksi akan menghasilkan produk lateks kering dengan kadar air sekitar 0,44-0,56\%, umpan berkadar air 75\% menghasilkan kadar air sekitar 0,400,58\%, umpan berkadar air 70\% kadar air produknya sekitar $0,35-0,48 \%$, dan umpan dengan kadar air 65\% akan menghasilkan produk berkadar air sebesar 0,32-0,34\%.

Air yang menguap dari tetesan umpan ini diidentifikasi sebagai air bebas. Air bebas mudah hilang apabila terjadi penguapan atau pengeringan dan dapat digunakan oleh 


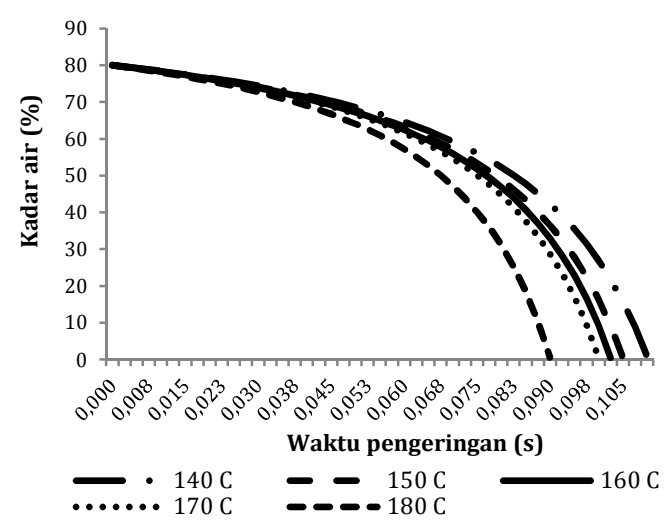

(a)

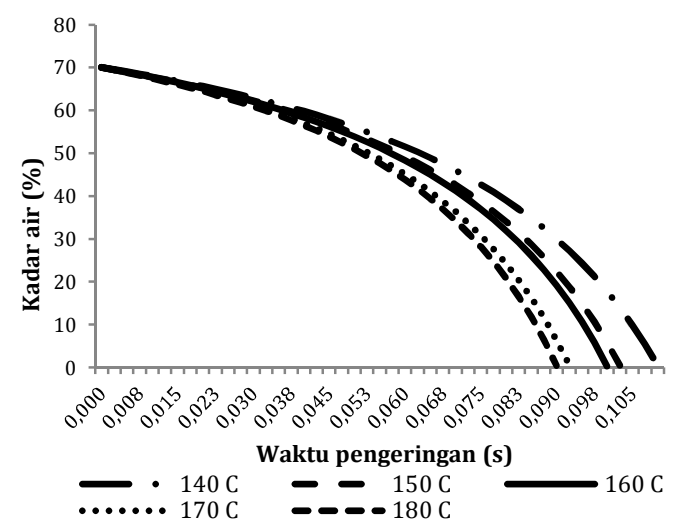

(c)

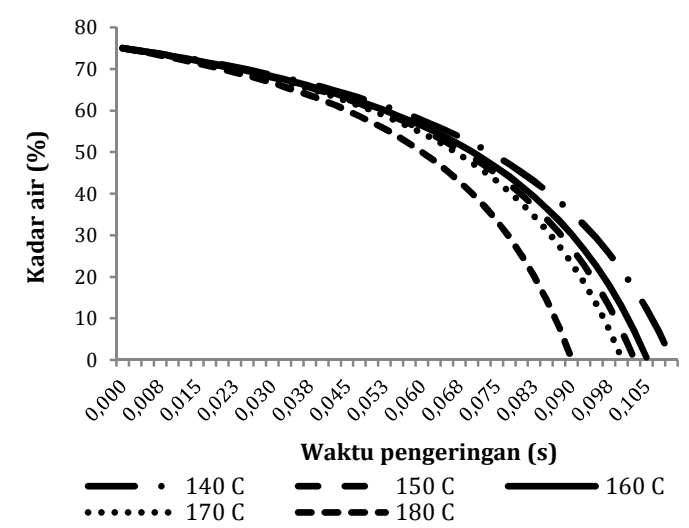

(b)

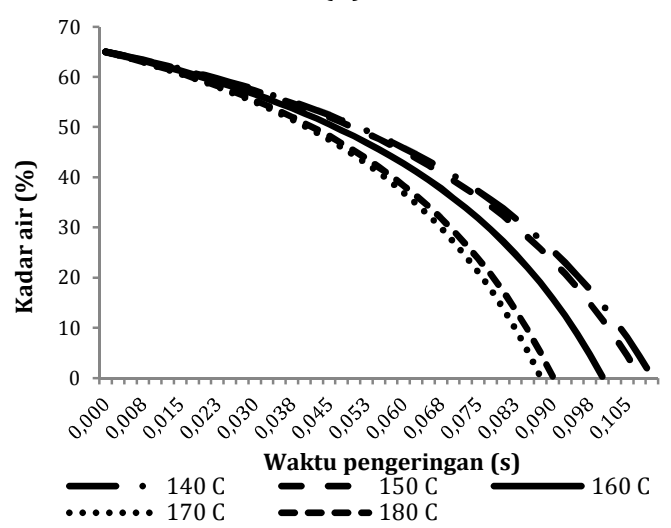

(d)

Gambar 5. Profil perubahan kadar air umpan lateks pada berbagai suhu udara pengering, (a) kadar air umpan $80 \%$, (b) 75\%, (c) 70\% dan (d) 65\%

mikroorganisme untuk pertumbuhan. Oleh karena itu dengan hilangnya air bebas pada pertumbuhan mikroorganisme sehingga tepung karet alam menjadi lebih tahan lama. Meski diprediksi memiliki kadar air bervariasi, produk yang dihasilkan sudah dapat dikategorikan karet kering. Kadar air dari karet kering sekitar 0,3-1,0\%.

Selain kadar air umpan, dari Gambar 5 juga dapat dilihat waktu pengeringan untuk setiap variasi pengeringan. Waktu pengeringan umpan dipengaruhi suhu udara pengering yang digunakan. Semakin tinggi suhu udara pengering, maka semakin cepat proses pengeringan. Waktu pengeringan tercepat 0,087 detik dihasilkan dari proses pengeringan menggunakan udara kering 180 ${ }^{\circ} \mathrm{C}$. Waktu pengeringan terlama 0,112 detik diperoleh dari udara kering $140{ }^{\circ} \mathrm{C}$. Dengan kondisi pengeringan yang sama, waktu pengeringan yang diperoleh dari simulasi CFD $(0,112$ detik $)$ hampir sama dengan perhitungan waktu pengeringan ketika perancangan pengering semprot $(0,134$ detik). Dengan waktu sekitar 0,087-0,112 detik, umpan lateks karet alam sudah kering sebelum menyentuh dinding ruang pengering. Hal ini terjadi karena waktu pengeringan lebih cepat dibandingkan waktu lintasan umpan di ruang pengering terutama yang berbentuk silinder. Hasil perhitungan menggunakan persamaan (9) untuk ruang pengering berbentuk silinder diperoleh bahwa waktu lintasan umpan sekitar 1,721,80 detik. Waktu lintasan umpan di dalam ruang pengering juga dipengaruhi suhu udara pengering (Gambar 6). Semakin tinggi suhu udara pengering, maka semakin cepat waktu yang dibutuhkan umpan di dalam ruang pengering.

Gambar 7 menunjukkan profil prediksi diameter tetesan lateks karet alam di dalam ruang pengering. Diameter tetesan yang disemprotkan mulut penyemprot dipengaruhi oleh kadar air yang terdapat di umpan lateks (Gambar 7). Hasil simulasi memprediksi bahwa diameter awal tetesan yang keluar dari mulut penyemprot hampir sama, yaitu sekitar $136 \mu \mathrm{m}$. Filkova dan Mujumdar (1995) menyatakan bahwa kisaran dari ukuran tetesan yang dihasilkan oleh mulut penyemprot bertekanan adalah 10-800 $\mu \mathrm{m}$. 


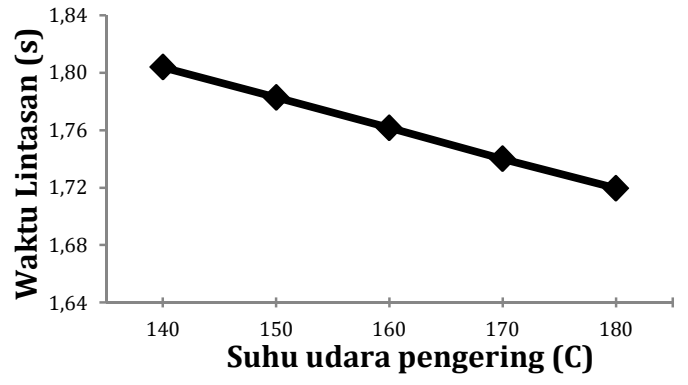

Gambar 6. Waktu lintasan umpan di ruang pengering atas yang berbentuk silinder

Selama proses pengeringan, tetesan akan mengalami perubahan ukuran menjadi lebih kecil atau penyusutan (shrinkage). Besaran penyusutan dan prediksi diameter akhir dari partikel produk kering dipengaruhi oleh kadar air awal umpan yang akan dikeringkan dan suhu udara kering yang digunakan. Semakin rendah kadar air umpan

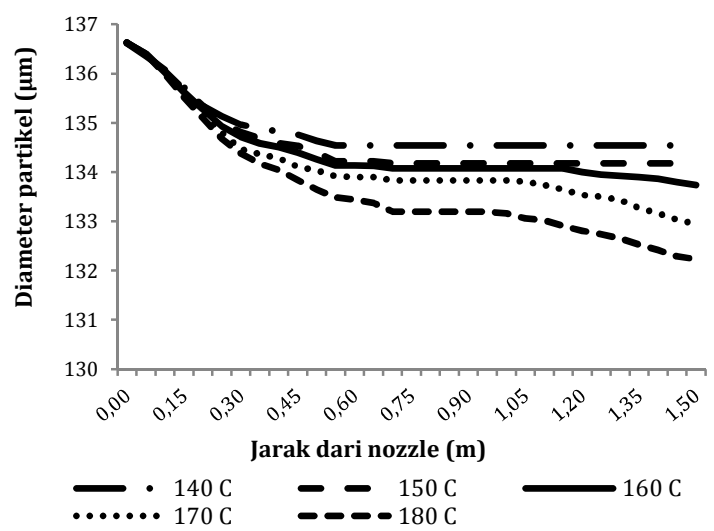

(a)

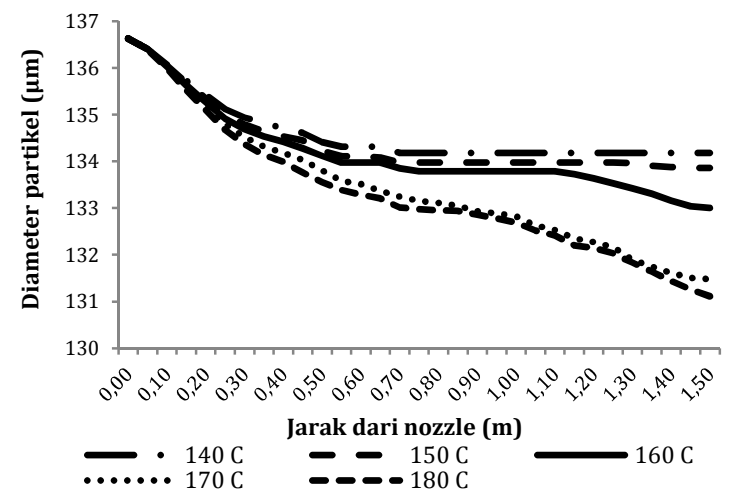

(c) dan semakin tinggi suhu udara kering, maka semakin kecil diameter produk akhir yang dihasilkan (Gambar 7).

Prediksi diameter akhir produk lateks kering yang terbesar $(134,54 \mu \mathrm{m})$ diperoleh dari proses pengeringan umpan dengan kadar air $80 \%$ menggunakan udara kering bersuhu $140{ }^{\circ} \mathrm{C}$. Sedangkan diameter terkecil $(130,5$ $\mu \mathrm{m})$ dihasilkan dari kombinasi pengeringan untuk umpan lateks berkadar air 65\% yang dikeringkan dengan udara bersuhu $180{ }^{\circ} \mathrm{C}$. Untuk pengeringan semprot dengan mulut penyemprot bertekanan, ukuran rata-rata produk kering yang dihasilkan bervariasi antara 50-250 $\mu \mathrm{m}$.

Penyusutan ini terjadi karena proses penguapan air bebas baik yang terdapat di permukaan partikel maupun di dalam partikel. Apabila pelarut yang terdapat di tetesan dikeluarkan dari partikel basah, bahan itu akan menyusut. Karena ukuran partikelpartikel karet yang sangat kecil (dalam ukuran mikrometer), penyusutan ini tidak menjadi masalah.

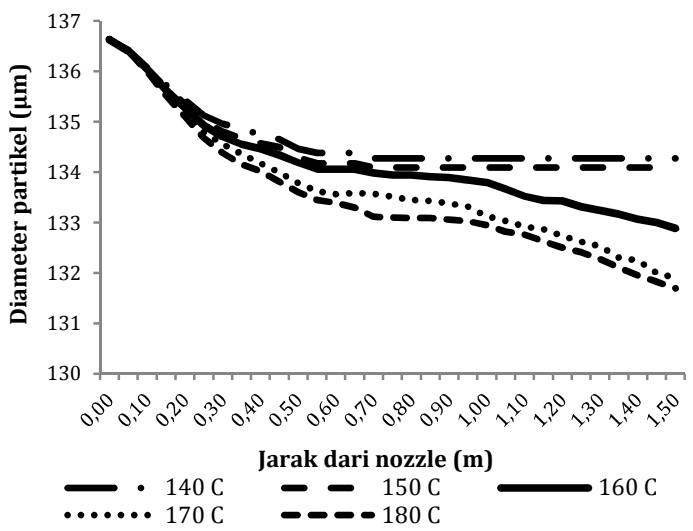

(b)

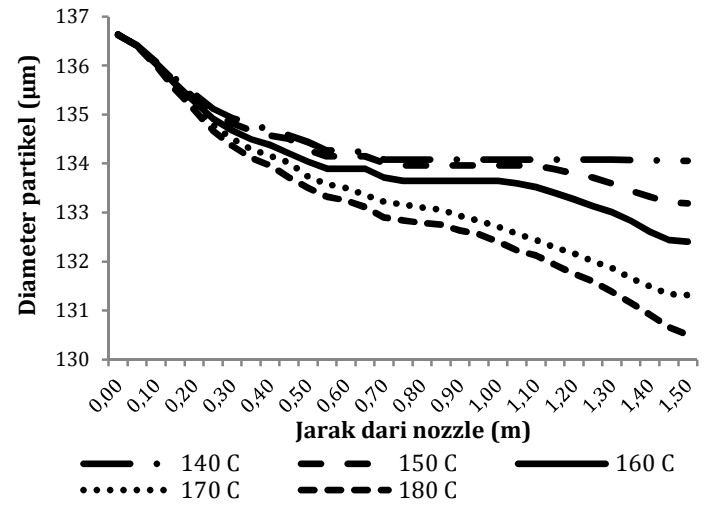

(d)

Gambar 7. Prediksi diameter tetesan karet di ruang pengering, (a) kadar air umpan $80 \%$, (b) $75 \%$, (c) $70 \%$ dan (d) $65 \%$ 


\section{KESIMPULAN}

Dari hasil penelitian yang sudah dilakukan dapat disimpulkan bahwa formulasi umpan untuk memproduksi tepung karet alam terdiri atas lateks segar, antikoagulan 1 $\%$-b, dan antilengket $2 \%$-b. Dimensi pengering semprot yang dirancang mempunyai diameter $1000 \mathrm{~mm}$ dengan tinggi bagian silinder $850 \mathrm{~mm}$ dan bagian kerucut $870 \mathrm{~mm}$ sehingga total volumenya sebesar $0,80 \mathrm{~m} 3$. Rancangan proses produksi tepung karet alam meliputi pengumpulan, pemeriksaan kualitas lateks, penyaringan, penambahan zat aditif, dan pengeringan. Hasil simulasi menunjukkan bahwa pengering semprot yang sudah dirancang mampu menghasilkan tepung karet alam. Kadar air tepung karet alam sekitar 0,32-0,56\% yang berarti bahwa tepung karet yang dihasilkan kering.

\section{DAFTAR NOTASI}

\begin{tabular}{|c|c|c|}
\hline $\mathrm{d}_{\mathrm{o}}$ & $\begin{array}{l}\text { diameter lubang mulut } \\
\text { penyemprot }\end{array}$ & $\mathrm{ft}$ \\
\hline $\mathrm{D}_{\mathrm{ch}}$ & $\begin{array}{l}\text { diameter minimum } \\
\text { ruang pengering }\end{array}$ & $\mathrm{ft}$ \\
\hline$D_{p}$ & $\begin{array}{l}\text { diameter } \\
\text { partikel/tetesan }\end{array}$ & $\mathrm{ft}$ \\
\hline$h^{\prime}$ & tinggi minimum & $\mathrm{ft}$ \\
\hline $\mathrm{h}_{\text {cone }}$ & $\begin{array}{l}\text { tinggi kerucut bagian } \\
\text { bawah ruang pengering }\end{array}$ & $\mathrm{ft}$ \\
\hline $\mathrm{k}_{\mathrm{f}}$ & konduktivitas panas & $\begin{array}{l}\text { Btu.ft } \\
/ \text { h.ft } \\
\text { F }\end{array}$ \\
\hline Q & laju alir umpan & $\mathrm{ft} / \mathrm{s}$ \\
\hline$r_{0}, r_{a}$ & $\begin{array}{l}\text { jari-jari lubang mulut } \\
\text { penyemprot dan jari- } \\
\text { jari inti udara }\end{array}$ & $\mathrm{ft}$ \\
\hline $\mathrm{r}_{\mathrm{c}}$ & $\begin{array}{l}\text { jari-jari ruang } \\
\text { pengering }\end{array}$ & $\mathrm{ft}$ \\
\hline $\mathrm{T}_{\mathrm{a}}, \mathrm{T}_{\mathrm{s}}$ & $\begin{array}{l}\text { suhu udara panas dan } \\
\text { suhu umpan }\end{array}$ & $\mathrm{F}$ \\
\hline $\mathrm{U}_{\mathrm{T}}, \mathrm{U}_{\mathrm{A}}$ & $\begin{array}{l}\text { kecepatan tangensial } \\
\text { dan kecepatan aksial }\end{array}$ & $\mathrm{ft} / \mathrm{s}$ \\
\hline $\mathrm{V}$ & $\begin{array}{l}\text { volume ruang } \\
\text { pengering }\end{array}$ & $\mathrm{ft}^{3}$ \\
\hline$\alpha^{\prime}$ & sudut penyemprotan & deg \\
\hline$\lambda$ & panas laten & $\begin{array}{l}\text { Btu/l } \\
\mathrm{b}\end{array}$ \\
\hline$\rho_{\mathrm{s}}$ & $\begin{array}{l}\text { konsentrasi air dan } \\
\text { konsentrasi } \\
\text { padatan/umpan }\end{array}$ & $\mathrm{lb} / \mathrm{ft}^{3}$ \\
\hline$\rho_{\mathrm{a}}$ & $\begin{array}{l}\text { densitas udara } \\
\text { pengering }\end{array}$ & $\mathrm{lb} / \mathrm{ft}^{3}$ \\
\hline$\theta_{\mathrm{d}}$ & waktu pengeringan & $\mathrm{h}$ \\
\hline
\end{tabular}

$\theta_{\mathrm{t}} \quad$ waktu lintasan

$\mathrm{h}$

\section{DAFTAR PUSTAKA}

Balai Penelitian Sembawa, Sapta Bina Usahatani Karet, Balai Penelitian Sembawa: Banyuasin, 2003.

Filkova, I.; Mujumdar, A. S., Industrial Spray Drying Systems. dalam Handbook of Industrial Drying, Vol.1, 2nd Ed.; Mujumdar, A. S., Marcell Dekker: New York, 1995.

Genskow, L. R.; Beimesch, W. E.; Hecht, J. P.; Kemp, I. C.; Langrish, T.; Schwartzbach, T.; Smith, L., Psychrometry, Evaporative Cooling, and Solid Drying. dalam Perry's Chemical Engineers' Handbook $8^{\text {th }}$ Edition.; The McGrawHil: New York, 2008.

Huang, L. X.; Mujumdar, A. S., A computational fluid dynamic study of a low humidity cocurrent pengering semprot, Asia-Pacific Journal of Chemical Engineering, 2007, 2(1) 12-19.

Kievert, F. G., Modelling Quality in Spray Drying; Proefschrift-Technische Universiteit Eindhoven: Netherland, 1997.

Patel, R. P.; Patel, M. P.; Suthar, A. M., Spray drying technology: an overview, Indian Journal of Science and Technology, 2009, 2(10), 44-47.

Saleh, S. N., CFD simulations of a co-current spray drayer, World Academy of Science, Engineering and Technology, 2010, 62, 772777.

Schweitzer, P. A., Handbook of Separation Techniques for Chemical Engineers, McGrawHill: New York, 1979.

Solichin, M., Pemanfaatan biji karet sebagai alternatif bahan pangan dan industri di Sumatera Selatan. Warta Pusat Penelitian Karet, 2000, 19(1-3), 55.

Zbicinski, I.; Zietara, R., CFD Model of Counter Current Spray Drying Process, Proceedings of the $14^{\text {th }}$ International Drying Symposium (IDS), Sao Paulo, Brazil, 22-25 Agustus 2004, Vol. A, hlm. 169-176. 